\title{
Gram-Negative Pleomorphic Bacillus
}

National Cancer Institute

\section{Source}

National Cancer Institute. Gram-Negative Pleomorphic Bacillus. NCI Thesaurus. Code C123469.

Any rod-shaped bacteria with variable length or shape that contains low levels of peptidoglycan in its cell wall and stains pink with the Gram staining technique. 